\title{
The opinion of the teachers and the pupils on teaching and learning at elementary school "Jovan Dučić”
}

\author{
Vesna Kostić, Jelena Mucić, Jovana Vasić
}

\section{Summary}

Changes in the contemporary society have brought a new way of working at schools. The traditional method of teaching was focused on the teacher and required the expertise of the teachers primarily as a lecturer. Active learning refers to the student who is directly involved in the learning process, whereas the teacher should give the students an intellectual incentive, encourage their curiosity and support them in their work.

The objective of this paper was to examine the students' and the teachers' opinions on the teaching process, on the methods and the ways of students' learning and the teachers' way of working in order to improve the quality of the teaching and the learning process itself. The research was carried out both among the students from the $5^{\text {th }}$ to the $8^{\text {th }}$ grade and the selected subject teaching teachers at school "Jovan Dučić". It was noted by descriptive analysis that there is a certain degree of disagreement in the way the students and the teachers see the teaching process. The research showed that the teachers should relate more material of their subjects to other school subjects, include more integrative and project teaching in their work as well as link school materials with everyday life. According to the students' answers, we can conclude that they would find the learning process more interesting if the experts in certain areas attended their lessons or if the elder students taught the younger ones. In addition, it is necessary to encourage students to strengthen their interdisciplinary competence 
and to link the acquired knowledge with the real requirements of the working context of the $21^{\text {st }}$ century. One of the important conclusions of our research shows that it is necessary to pay more attention to the individual characteristics of each student. By adopting these changes in the working process, the teachers would approach the principles of active learning, whereas the students would be more prepared for the future.

Key words: teaching, learning, student differentiation in teaching, multiple linking of teaching materials, career guidance for students.

\section{Background and the research purpose}

The characteristics of teaching which support creativity are consistent with the characteristics of good teaching and models of successful learning (De Corte, 2013; Desforges, 2001; Dryden, Vos, 2001; Meyer, 2005; 2009). ${ }^{\mathrm{I}}$ Starting with this thesis, we wanted to determine the degree up to which this model could be applied to our school.

The research on the way students learn, as well as the way the teachers at elementary school "Jovan Dučić" organise the teaching process, was carried out as a part of the planned activities of the team for the School Development Plan (SDP). Considering the previous researches, the students' results at the final exam, as well as the students' results at the competitions in the past period, the SDP team came to the conclusion that it is necessary to focus the teaching team on achieving even better results at the final exam and improving the teaching process, in general, as well as building a relationship of mutual understanding between students and teachers. Learning involves a change in achievement over time (Anderson, 2013: 22). The first and the most significant condition of continuous learning is to know how to learn. The specific goal of the research, which is based on the self-assessment of the students' and teachers' achievements, was to identify the specific learning and teaching problems the students and the teachers face with. It was primarily the students' learning habits, how much they understand the material, how much time they spend learning in classes and at home on their own, what makes learning easier for them, how much material from different subjects they connect with everyday life, that really interested us in this research. During the research, we paid special attention to the teachers' way of working and to the way both students and teachers see

$1 \quad$ Slavica Maksić and Jelena Pavlović, "Teaching That Supports Creativity," in Teaching and Learning - the Quality of the Educational Process - Ed. Radmila Nikolić (Kragujevac, Serbia: University of Kragujevac, 2013), 61. 
it. We were questioning how the students and the teachers see the teaching process, how much their opinions coincide, how much they differ, how the criteria for assessment are seen by students and by teachers. The results of the research will be used for identifying and continuous solving all the weaknesses in the subject teaching.

\section{Methodology}

The total number of the students from the $5^{\text {th }}$ to the $8^{\text {th }}$ grade who attended the lectures during the research at the time was 263 . The research was carried out on a sample of 176 students, out of which 82 were male (46.6\%) and 94 female students (53.4\%). 36 of them are the $5^{\text {th }}$ graders, 62 students are the $6^{\text {th }}$ graders, 32 students are the $7^{\text {th }}$ graders and the rest 46 students are the $8^{\text {th }}$ graders.

\section{Tabela 49: Structure of the sample in relation to the class that respondents attend}

\begin{tabular}{|c|c|c|}
\hline Grade & Frequency & Percentages \\
\hline $5^{\text {th }}$ & 36 & 20.5 \\
\hline $6^{\text {th }}$ & 62 & 35.2 \\
\hline $7^{\text {th }}$ & 32 & 18.2 \\
\hline $8^{\text {th }}$ & 46 & 26.1 \\
\hline Total & 176 & 100.0 \\
\hline
\end{tabular}

The other part of the respondents includes 20 out of 23 subject teachers in our school. The measuring instruments used in this research include two questionnaires specially designed for this purpose: 1 . The student questionnaire- contains 49 questions of the five-step Likert scale where 1 represents a complete disagreement, and 5 is a complete agreement with the claim. The first 20 items relate to the students' habits while learning and the remaining 29 items relate to the way students see the quality of teaching at school. 2. The teacher questionnaire - contains $30 \mathrm{qu}-$ estions in the form of the five-step Likert scale. The items refer to the way of teaching process. Unlike students' questions, the questions for the teachers were put in the first person in order to give teachers an opportunity to express their opinions on their way of working. Descriptive values were analysed in the SPSS statistical programme. Quantitative methods were used in data processing. 


\section{Research procedure}

The survey in the classes from the $5^{\text {th }}$ to the $8^{\text {th }}$ grade was conducted in November and December in 2018. Although it was carried out in the peer classes, the participation was voluntary. The teachers filled the questionnaire voluntarily as well. Before they completed the questionnaire, they had been familiarised with both the structure of the questionnaire and the objectives of the research. They had been also familiarised with the method of inputting the answers and the anonymity was guaranteed at the same time. The questionnaire lasted on average about 15 minutes.

\section{Results}

The first part of the analysis included the analysis of the students' opinion on learning and teaching at school. We will point out the most indicative students' responses ${ }^{2}$, which can be good guidelines for the teachers in their future work. We can notice that the students, on average, showed a high degree of agreement with the statements related with the first part of the questionnaire (questions from 1 to 20), where they answered the questions related to their way of learning. Most students agree with the statement "the more they like a particular school subject, the more easily they acquire it". Furthermore, they try hard to memorise the most significant things in the text, to understand what they read and to follow and listen to their teachers' lectures so as to learn as much as possible in class. A great majority of the students from the $5^{\text {th }}$ to the $8^{\text {th }}$ grade agreed with the statement: "I start learning by trying to realise what exactly I have to learn" $(\mathrm{M}=4.05, \mathrm{SD}=1.264)^{3}$ and "While learning I try to remember everything that has been written" ( $M=4.05, S D=1.197$ ), whereas a small number of students agreed with the statement: "I am not interested in learning at school because the content is boring" ( $M=2.58, \mathrm{SD}=1.488$ ). Most students think that they put a lot of effort into learning because they care about the success. During the learning process they often use tables, charts and pictures. According to the students' answers we can see what their learning habits are like. While learning, most students repeat old material although they do not have bad marks and they also try to understand how information from the classroom can be used in everyday life.

2 „SDP - results of research on teaching and learning“, Primary School Jovan Ducic, last modified April 20, 2019, https://www.jovanducic.edu.rs/wp-content/uploads/2019/04/20/SRP_rezultati_istrazivanja_o_nastavi_i_ucenju.pdf 
Concerning the questions from 21. to 49. in the questionnaire in which the students write about the school teaching, we notice that the students showed a high degree of agreement with the statements that the teachers praise them for both their successful work and activity in class $(M=3.89$, $\mathrm{SD}=1.269$ ), and that the teachers answer the students' questions related to the school material $(M=3.88, S D=2.234)$. The students also said that the teachers emphasised the most important parts of the lesson in order to make it easier for students to learn $(\mathrm{M}=3.84, \mathrm{SD}=1.321)$. Also, they say that it is important for them to be given the marks publicly and with an explanation. The students appreciate the use of ICT in class, too.

On the other hand, we also notice that the students' opinions on teaching differ from the teachers' opinions and they largely disagree with the statements referring to the teachers' way of working. The students note that the teachers, while giving a lecture, present facts without asking any questions, and when they work in groups, they do not receive a specific assignment from the teacher. The teachers answer the students' questions to a greater extent than the students really think they do. Both claim that the experts do not attend their lessons. There is a big difference in the assessment of claims regarding the support of students' unusual ideas when solving a task, because students consider it to be less $(\mathrm{M}=3.17, \mathrm{SD}=1.383)$ than teachers think $(M=4.60, S D=0.681)$. The same goes for the claims that the teachers insist on linking materials from different fields and that the teachers provide students with useful pieces of advice regarding the way they learn, because the students rate it lower than the teachers themselves.

\section{Conclusions}

All students' and teachers' assessments of the claims are quite different, which leads us to more conclusions. We can assume that the students have a different experience of teaching and learning compared to the teachers, but there is enough room for learning progress and improving the teaching process. Memorising facts and learning what has been written should show both students and teachers that changes in teaching and learning process are necessary. The students haven't fully mastered the learning techniques, they do not often apply critical thinking and see the connection among different school subjects, which makes their learning more difficult. On the other hand, the teachers do not sufficiently apply new techniques of working with students which would make them more active in class. The older the students are the less they are interested in learning, so it is necessary 
to determine more detailed measures to support the students and to work on updating the teaching process which will be in accordance with everyday needs, but primarily with the students' age who the teaching is designed for. This leads us to the conclusion that coordination of activities of several teachers or subjects could lead to the progress of the teaching process. Students could be put in a situation where the use of subject and cross-curricular competences are required, and a situation where the student will not copy their already acquired knowledge but will acquire new knowledge. Considering the research results, we can conclude that the learning process should take place as much as possible in class. We suggest more group and individual work, setting research tasks, solving problem situations. Learning would be easier if there were more room for greater use of different tasks which are in accordance with students' abilities. It is necessary for the teachers to pay more attention to individual characteristics of each student, although it is hardly feasible nowadays.

In general differentiation accepts all the aspects of teaching (or curriculum). That means that the content, the process and the expected products of learning can be easily adapted (Altaras Dimitrijevic in Tatic Janevski, 2016: 87).

A greater teacher's creativity, which involves the integrative and project teaching and connects the school material with everyday life, leads to the greater quality of teaching process and easier adopting the material. In order to motivate students to learn, it is necessary to emphasize the importance of the knowledge acquired by learning various subjects for their future employment (Cizmic et al, 2016: 163). Teachers should train students as much as possible during classes to make important decisions in order to later choose an appropriate high school. The goal for students is to master their own career management skills as much as possible and become aware of their interests in terms of future occupation.

By adopting and applying all these recommendations, we believe that the teaching process as well as the learning process would significantly improve in our school. This is a continuous process which takes place in accordance with contemporary trends in society, but which also starts with the personal readiness of each individual to accept and apply them. 


\section{Literature}

Altaras Dimitrijević, Ana, Tatić Janevski S., "Education of Students of Exceptional Abilities: Scientific Basics and Guidelines for School Practice.”, Belgrade, Serbia: Institute for the Advancement of Education, 2016.

Maksić Slavica and Pavlović Jelena in Nikolić, R. (Ed.) “Teaching That Supports Creativity" in Teaching and Learning - the Quality of the Educational Process, 53-64. Kragujevac, Serbia: University of Kragujevac, 2013.

Anderson, Lorin W., "Teaching that causes change: perspectives and an overview”, in: Anderson Lorin W. (Ed.) “(pdf) Teaching for Learning - A reference guide for results-oriented teachers”, 15-35. Thessaloniki: Center for Democracy and Reconciliation in Southeast Europe, 2013.

Čizmić, Svetlana, Ivana B. Petrović, and Milica Vukelić. "Challenges of the 21st Century for the Career Education of Primary School Students' Career Education." Essay. In Proceedings of the International Scientific Conference Improving the Quality of Education in Primary Schools: Proceedings:14. October 2016., Beograd, 161-165. Belgrade, Serbia: Institute for Pedagogical Research, 2016.

\section{Sources}

School Development Plan - Research Results on Teaching and Learning. Belgrade, Serbia: Primary School Jovan Dučić, Last modified April 20, 2019. https://www.jovanducic.edu.rs/wp-content/uploads/2019/o4/20/SRP_rezultati_istrazivanja_o_nastavi_i_ucenju.pdf 